\title{
Legal Protection for Umrah Pilgrims During the Covid-19 Pandemic
}

\author{
Sugeng Riyadi ${ }^{1}$, Suparno $^{2}$ \\ Student Program Doctor of Law Borobudur University, Jl. Pemuda, RT.1/RW.3, \\ Rawamangun, Kec. Pulo Gadung, DKI Jakarta 13220, Indonesia ${ }^{1,2}$ \\ \{Andri_anugerah@yahoo.com¹,suparno@borobudur.ac.id² $\}$
}

\begin{abstract}
The Covid-19 pandemic causes religious activities to be delayed, even though, over time, religious activities are carried out adaptively to the virus. This paper discusses the legal protection of pilgrims who canceled their departure due to the Covid-19 pandemic. The method used in this study is empirical juridical, which uses a descriptive-analytical approach as an analytical knife. The data used in compiling this paper is literature and legislation data, and the analysis used is the qualitative analysis method. The study results obtained are the cancellation of Umrah's departure in 2020 due to the Covid-19 pandemic while the pilgrims have paid in full. Legal protection in the form of compensation reimbursement, both material and immaterial and rescheduling, is in Law No. 8 of 1999 on Consumer Protection.
\end{abstract}

Keywords: legal protection; Congregation of Umrah; Cancellation, Covid-19

\section{Introduction}

Indonesia is a heterogeneous country with many different ethnic groups, religions, and languages. The constitution guarantees this, including the protection of carrying out worship according to its inhabitants' religion and belief. In Islam, worship has the meaning of servitude and submission to Allah SWT. Carrying out worship in religion is a must, even though the law of carrying out worship in sharia has several variants.

One of the worship practices carried out by Muslims around the world is Umrah. As instructed by the Qur'an in Surah Al Baqarah verse 158 above, the Indonesian state guarantees the rights of citizens as evidenced by Article 29 Paragraph (2) of the 1945 Constitution of the Republic of Indonesia, which states that: "The state guarantees independence each resident to embrace their respective religions and to worship according to that religion and belief. "

The implementation of the Umrah pilgrimage trip is a series of Umrah pilgrimage travel activities outside the Hajj season, which includes guidance, service, and protection of the congregation, which is carried out by the Umrah pilgrimage trip. In the future, the Umrah pilgrimage organizer, abbreviated as PPIU, is a travel agency that has received permission from the Minister to organize an Umrah pilgrimage trip (Pesulima \& Hetharie, 2020).

The Government must supervise umrah organizers through several regulations or laws and regulations. The legal basis for organizing the Umrah pilgrimage is guided by Law Number 13 of 2008 concerning Hajj and Umrah's implementation. The implementation of Umrah must 
comply with regulations. The Government is obliged to supervise as regulated also in the Regulation of the Minister of Religion No. 8 of 2018 Article 19 that: (1) the organizers of Umrah need to make reports on the implementation of umrah trips, including umrah travel plans, departures, and repatriations, (2) reports on the implementation Umrah trips as referred to in paragraph one include: (a) guidance for Umrah worship; (b) departure and return data; (c) Acceptance and issuance of a congregational visa; (d) The congregation's problems and solutions (Muhammad et al., 2020).

Many problems are faced, especially regarding the protection of the Umrah congregation, in this case, the Umrah bureau's consumers. They are disadvantaged due to regulatory issues and technical problems in the field. In this paper, the author only focuses on protecting consumers from Umrah pilgrims to cancel umrah worship trips due to the Covid-19 pandemic. The Government's protection and compensation through the Haj and Umrah bureaus for Umrah pilgrims who canceled their departure.

\section{Methods}

The approach method used in this research is a juridical-empirical approach. This study uses a procedure to solve problems in the empirical juridical method by examining secondary data first, then examining the primary data in the field related to the implementation of standard Umrah clauses.

\section{Discussion}

\subsection{Regulations on the Implementation of Umrah Worship in Indonesia}

The regulation of Umrah in Indonesia is regulation through Law No. 8 of 2019 concerning Hajj and Umrah's implementation. Consideration of the increasing number of citizens to perform hajj and Umrah makes the Government need to improve the quality of hajj and umrah services automatically safe, orderly, comfortable, and following the provisions of sharia. Even specifically, the Ministry of Religious Affairs made regulation of the ministry of religionrelated to the implementation of Umrah by issuing a regulation of the Minister of Religious Affairs of the Republic of Indonesia Number 8 of 2018 concerning the Implementation of Umrah Pilgrimage (Agustino, 2020).

Responding to the pandemic administration condition, umrah worship that departs to the holy land should refer to the Decree of the Minister of Religious Affairs No. 719 of 2020. The regulation is a guideline for the implementation of Umrah during the Covid-19 pandemic. The follows an announcement from the Government of Saudi Arabia that reopens Umrah in 2020. For prospective pilgrims, all must comply with the requirements of pilgrims who can leave and comply with health protocols before, when and until returning to the country.

The Umrah pilgrimage trip organizers must pay attention to the quarantine mechanism and the prospective congregation, pay attention to the departure quota, and pay attention to the reporting of the departure, arrival, and return of the prospective congregation. This regulation was preparing to protect the Umrah congregation per the mandate of Law No. 8 of 2019 concerning Hajj and Umrah's implementation and has referred to the Haj pilgrimage guidelines established by Saudi Arabia. 
There is no transmission during the congregation undergoing the Umrah pilgrimage. Prevent transmission if the congregation complies with health protocols. Washing hands, wearing masks, maintaining distance (3M), and Umrah officers' direction in the field. Umrah worship policies will continue to be monitored and evaluated according to the development of the Covid-19 pandemic in Indonesia and Saudi Arabia. "We must remember that implementing health protocols can effectively reduce the risk of Covid-19 transmission. There reminds us that the value of cooperation in the Penta helix collaboration determines the success of handling Covid-19.

Given the short time between the Saudi Arabian Government's decision and preparation for departure, the massive socialization of health protocols for Umrah pilgrimage during the pandemic must be carried out thoroughly by involving the regional offices of the Ministry of Religion in each region.

It also utilizes methods and media that adjusted to the prospective Umrah pilgrims' characteristics and their regions of origin. It is essential for people who will carry out the Umrah pilgrimage to know and comply with the conditions set out in the Decree of the Minister of Religion No. 719 of 2020.

\subsection{Legal Protection Organizing Umrah worship during the Covid-19 Pandemic}

Regulations related to hajj have been regulated in Law No. 8 of 2019 concerning Hajj and Umrah's implementation. Even responding to the Covid-19 pandemic, the Government, through the Ministry of Religious Affairs, issued a Decree of the Minister of Religious Affairs No. 719 of 2020 concerning Guidelines for the Implementation of Umrah Pilgrimage During the Corona Virus Disease Pandemic 2019 (Covid-19).

Referring to the Government of Saudi Arabia's policies, the Government has set guidelines for the pilgrimage during the Covid-19 pandemic on condition that the pilgrims leave during the Covid-19 pandemic according to the provisions of the Government of Saudi Arabia, such as being free Covid-19 Evidence and having been vaccinated. Evidence of COVID-19 free with PCR / Swab test results issued by a hospital or laboratory-verified by the Minister of Health is valid for 72 hours from sampling until Umrah departure.

During the worship in the holy land Jemaah, Umrah must comply with health protocols that Saudi Arabia has established. Umrah organizers are responsible for implementing health protocols during the implementation of Umrah from departure, travel, and while in Saudi Arabia. During the departure of Umrah, umrah organizers are responsible for quarantine both in the country and during the journey until arriving in Saudi Arabia. As long as the pilgrims are and leave the quarantine place, it is mandatory to follow Saudi Arabia's health protocols.

Umrah departure activities during the Covid-19 pandemic only departed from SoekarnoHatta Airport Banten, Juanda Airport East Java, Sultan Hasanuddin South Sulawesi, and Kualanamu North Sumatra. There is to ensure certainty in the control and supervision of pilgrims' eradication and repatriation during the Covid-19 pandemic. Umrah organizers are responsible for providing transportation facilities since quarantine locations, departure airports, roundtrip aircraft, and transportation in Saudi Arabia.

Umrah pilgrims are entitled to apply for rescheduling of departures and applying for cancellation of departures in the case of legal protection. In connection with the cancellation of the congregation is entitled to a refund of the fee paid. Umrah's management is entitled to refund the cost of the service package to the congregation in case of cancellation caused by technical or non-technical problems. 


\section{Conclusion}

The cancellation of hajj trips conducted unilaterally by the hajj travel agency provides losses to prospective pilgrims both materially and immaterial. Through the Consumer Protection Act, the state is still trying to provide legal protection through court channels. The form of legal protection that can apply to Hajj and Umrah travel agencies is in the form of sanctions based on the Consumer Protection Law in the form of compensation that will be decided in court based on the panel's consideration judges compensation in the name of good. Cleaning because the prospective Umrah pilgrims have published the results of the villagers' study around the residence of the prospective Umrah pilgrims. However, in the case of cancellation due to the Covid-19 pandemic, it is an extraordinary thing, not $100 \%$ the umrah organizers' fault. The handling of legal protection is more towards protecting citizens as not to be exposed to coronavirus.

As for the existing legal protection against cases of unilateral cancellation of the agreement on prospective Umrah pilgrims, Umrah is the award of compensation to the party who was harmed, in this case, is a prospective pilgrim umrah. The travel agency must also give the good name of the prospective pilgrims through the national media.

\section{References}

[1] Agung Putu Wiwik S, Lis Julianti. 2020. "Penanggulangan Covis-19 Berbasis Desa Adat Dalam Perspektif Perlindungan Hukum Terhadp Aparatur Desa Adat.” Prosiding Seminar Nasional Webinar Nasional Universitas Mahasaraswati Denpasar "Percepatan Penanganan COVID-19 Berbasis Adat di Indonesia": 71-76.

[2] Agustino, Leo. 2020. "Analisis Kebijakan Penanganan Wabah Covid-19: Pengalaman Indonesia Analysis of Covid-19 Outbreak Handling Policy: The Experience of Indonesia." Junal Borneo Administrator 16(2): 253-70.

[3] Ariany, Farida, and Murtiana Ningsih. 2019. "Perlindungan Hukum Terhadap Identitas Pasien Covid 19.” Journal of Chemical Information and Modeling 53(9): 1689-99.

[4] Mukhlis, Sihabudin. 2018. "Perlindungan Hukum Jemaah Umrah Dalam Penyelenggaraan Perjalanan Ibadah Umrah.” Asy-Syari'ah 20(1): 49-58.

[5] Muhammad, Ilyas, Bambang Winarno, and Rachmad Safa'at. 2020. “Jurnal Ilmiah Pendidikan Pancasila Dan Kewarganegaraan.” Jurnal Ilmiah Pendidikan Pancasila dan Kewarganegaraan 5(1): 131-38. http://journal2.um.ac.id/index.php/jppk/article/view/7820/3749.

[6] Nathasya Victoria Ruswandana*, Bambang Eko Turisno, Suharto. 2016. "Perlindungan Hukum Terhadap Konsumen Dalam Pembatalan Keberangkatan Ibadah Haji Khusus Oleh Biro Penyelenggara Ibadah Haji Khusus.” Diponegoro Law Review 5(3): 1-12.

[7] Pesulima, Theresia Louize, and Yosia Hetharie. 2020. "Perlindungan Hukum Terhadap Keselamatan Kerja Bagi Tenaga Kesehatan Akibat Pandemi Covid-19.” Pesulima, Theresia Louize Hetharie, Yosia 26(2): 280.

[8] Suryani, Dewi Ervina. 2013. "Perlindungan Hukum Terhadap Penetapan Status Covid19 Pada Pasien Penyakit Umum Oleh Rumah Sakit Di Kota Medan.” Jurnal Hukum Kaidah 20(2): 127-35. 
[9] Sholikin, M Nur, and Herawati. 2020. "(Legal Aspects of Occupational Safety and Health for Medical and Health Workers During the Pandemic)." Majalah Hukum nAsional 50(2): 1-20.

[10] Tuwu, Darmin. 2020. "Kebijakan Pemerintah Dalam Penanganan Pandemi Covid-19." Journal Publicuho 3(2): 267. 